\title{
Collaborative Governance Dalam Program Perhutanan Sosial Pada HKm Gempa 01 Kurau Barat Bangka Belitung
}

\author{
Bambang Ari Satria ${ }^{1}$, Hermianto ${ }^{2}$ \\ 12Program Studi Ilmu Administasi Negara STISIPOL Pahlawan \\ bambang.ari.satria@stisipolp12.ac.id, hermianto1@gmail.com
}

\begin{abstract}
ABSTRAK
Tata kelola hutan oleh rakyat merupakan pendekatan baru dalam perhutanan sosial. Pemanfaatan dan pengelolaan perhutanan sosial di Provinsi Kepulauan Bangka Belitung dilakukan dalam rangka memberi akses bagi masyarakat dalam pemanfaatan hutan menjadi lebih baik untuk meningkatkan taraf ekonomi masyarakat. Salah satunya adalah Hutan Kemasyarakatan (HKm) Gempa 01 Kurau Barat Bangka Belitung. Penelitian ini berjudul collaborative governance dalam pemanfaatan perhutanan sosial pada HKm Gempa 01 Kurau Barat Bangka Belitung. Tujuan penelitian ini untuk mendeskripsikan bagaimana pelaksanaan collaborative governance dalam pemanfaatan perhutanan sosial pada $\mathrm{HKm}$ Gempa 01 Kurau Barat Bangka Belitung. Teori yang digunakan adalah teori collaborative procces Chris Ansell dan Alison Gash. Metode yang digunakan dengan pendekatan penelitian kualitatif. Teknik pengumpulan data menggunakan wawancara, observasi dan audio visual. Hasil penelitian menunjukkan bahwa proses kolaborasi antar pemangku kepentingan yang terlibat dalam program perhutanan sosial pada HKm Gempa 01 Kurau Barat Bangka Belitung sudah berjalan dengan baik. Hal itu ditandai dengan meningkatnya dampak ekologis dan dampak ekonomis bagi masyarakat di Desa Kurau Barat melalui pemanfaatan program perhutanan sosial dan prestasi yang diraih HKm Gempa 01 Kurau Barat sebagai Juara 1 tingkat nasional kategori Hutan Kemasyarakatan pada Tahun 2019.
\end{abstract}

Kata Kunci : Collaborative Governance, Perhutanan Sosial, Hutan Kemasyarakatan

\section{ABSTRACT}

Forest governance by the people is a new approach in social forestry. Utilization and management of social forestry in the Province of Bangka Belitung Islands is carried out in order to provide access for the community to manage forests sustainably to improve community welfare. One of them is Community Forest (HKm) Earthquake 01 West Kurau, Bangka Belitung. This research is entitled collaborative governance in the utilization of social forestry in the HKm Gempa 01 West Kurau Bangka Belitung. This study aims to determine how the implementation of collaborative governance in the use of social forestry in the HKm Gempa 01 West Kurau Bangka Belitung. The theory used is the theory of collaborative processes by Chris Ansell and Alison Gash. This study used qualitative research methods. Data collection techniques using interviews, observation and audio visual. The results showed that the collaborative process between stakeholders involved in the social forestry program at HKm Gempa 01 West Kurau Bangka Belitung had gone well. This is marked by the increasing ecological impact and economic impact on the community in West Kurau Village through the use of social forestry programs and the achievements of HKm Gempa 01 Kurau Barat as 1st winner at the national level in the Community Forest category in 2019.

Keywords: Collaborative Governance, Social Forestry, Community Forest 


\section{PENDAHULUAN}

Hutan dimanfaatkan untuk kepentingan rakyat adalah paradigma baru dalam program perhutanan sosial (Kuncoro, 2018). Pergeseran tata kelola hutan bukan hanya untuk kepentingan kelompok usaha besar saja melainkan masyarakat di sekitar hutan perlu mendapat jaminan izin atau hak untuk pengelolaan dan pemanfaatan hutan tersebut. Hutan merupakan salah satu sumber daya alam yang memiliki nilai guna dalam proses kehidupan manusia untuk berbagai kepentingan mulai dari sosial, ekonomi, dan bahkan lingkungan sehingga hutan tersebut perlu dijaga keberadaan dan fungsinya agar tetap menjadi baik (Nilasari, Murtilaksono, \& Soetarto, 2017).

Pelaksanaan program prioritas negara dalam mencapai kemandirian ekonomi dalam bidang kehutanan adalah komitmen pemerintah dalam hal ini dilakukan oleh Presiden Republik Indonesia dengan mengalokasikan luas kawasan hutan sebanyak 12,7 juta hektar untuk pemanfaatan program perhutanan sosial. Program-program tersebut mulai dari hutan tanaman rakyat, hutan kemasyarakatan, hutan desa, hutan adat dan kemitraan pengelolaan hutan. Regulasi yang mengatur hal tersebut dalam tingkatan kementerian adalah Peraturan Menteri LHK (Lingkungan Hidup dan Kehutanan) RI Nomor P.83/Menlhk/Setjen/Kum.1/10/2016 tentang Perhutanan Sosial (Kementerian Lingkungan Hidup dan Kehutanan, 2016).

Menurut Kuncoro (Susilo, 2019) perhutanan sosial dimaknai sebagai sistem tata kelola hutan agar lestari yang kemudian diimplementasikan dalam area hutan milik negara dan dilaksanakan oleh masyarakat sekitar hutan sebagai aktor utama yang berfungsi untuk peningkatan taraf ekonomi masyarakat, menjaga keseimbangan lingkungan dan perubahan sosial budaya dalam bentuk Hutan Desa (HD), Hutan Kemasyarakatan (HKm), Hutan Tanaman Rakyat (HTR), Hutan Adat (HA), dan Kemitraan Kehutanan. Selain peraturan menteri pada level kementerian yang mengatur tentang perhutanan sosial, di level direktur jenderal juga dibuat aturan teknis dalam rangka mempercepat program perhutanan sosial tersebut. Beberapa regulasi tersebut antara lain Peraturan Dirjen Perhutanan Sosial dan Kemitraan Sosial Nomor P.14/PSKL/Set/PSL.0/112016.

Peraturan tersebut mengatur mengenai pedoman fasilitasi, pembentukan dan tata cara kerja kelompok kerja percepatan perhutanan sosial. Ada juga Keputusan Dirjen Perhutanan Sosial dan Kemitraan Lingkungan Nomor SK.23/PSKL/SET/KUM.1/9/2017 tentang Pembentukan Kelompok Kerja Percepatan Perhutanan Sosial (Kementerian Lingkungan Hidup dan Kehutanan, 2017). Tak hanya di level pusat, komitmen pemerintah daerah dalam menyukseskan program perhutanan sosial juga tampak. Seperti halnya dilakukan oleh Pemprov Babel dengan diterbitkannya Keputusan Gubernur Babel Nomor: 188.44/1350/Dishut/2017 tentang Pembentukan dan Struktur Organisasi Kelompok Kerja Percepatan Perhutanan Sosial Provinsi Kepulauan Bangka Belitung Tahun 2017-2022 (Dinas Kehutanan Provinsi Kepulauan Bangka Belitung, 2017). Pembentukan pokja tersebut dalam rangka agar pembangunan kehutanan berkelanjutan di Provinsi Kepulauan Bangka Belitung dapat mengurangi laju deforestasi serta konflik tenurial dan memberi akses bagi masyarakat dalam tata kelola hutan agar tetap lestari dan dapat meningkatkan taraf ekonomi masyarakat di sekitar hutan yang sedang dikelola. 
Kebijakan perhutanan sosial diharapkan memberikan solusi terhadap pengangguran, kemiskinan, konflik lahan, rehabilitasi lahan dan penyediaan rasa aman kepada masyarakat dengan memberi mereka akses secara legal terhadap sumber daya hutan dan kawasan hutan (Putra et al., 2019). Tugas pokok dan fungsi yang diemban Pokja PPS antara lain adalah penyampaian informasi program perhutanan sosial, fasilitator bagi masyarakat yang melakukan ijin permohonan untuk mendapatkan akses legal pengelolaan hutan, verifikasi permohonan akses legal pengelolan hutan, melakukan aktivitas peningkatan kapasitas pengelola dan kelembagaan kelompok kehutanan, dan memfasilitasi pengembangan usaha serta pemasaran produk dari program perhutanan sosial tersebut.

Di dalam pelaksanaan program perhutanan sosial, terdapat permasalahanpermasalahan yang dihadapi. Identifikasi yang dilakukan peneliti, permasalahan tata kelola kawasan hutan yang ada di beberapa kabupaten di Provinsi Kepulauan Bangka Belitung antara lain adalah terbatasnya tingkat pengetahuan masyarakat tentang tata izin perhutanan sosial, terbatasnya sumber daya pengelola, terbatasnya modal pembiayaan awal dan masih terdapat penolakan dari kalangan masyarakat terhadap keberadaan hutan tanaman industri yang banyak dikuasai oleh kelompok kepentingan pemodal.

Untuk itu, diperlukan sinergitas dan kolaborasi antar pemangku kepentingan yang terlibat dalam capaian pemanfaatan dan pengelolaan perhutanan sosial. Sinergitas dan kolaborasi sangat penting dan berperan dalam mencapai kehidupan masyarakat yang sejahtera, pembangunan yang merata dalam kehidupan masyarakat kelompok tani hutan. Kini, ada beberapa kegiatan pemerintah yang menjadi sorotan utama terkait dengan pengelolaan hutan sebagaimana tertuang dalam program perhutanan sosial, yakni peningkatan taraf ekonomi masyarakat khususnya yang berada di sekitar kawasan hutan dan juga pencarian model penjagaan hutan agar tetap lestari secara tepat. Melihat tujuan baik tersebut, pemerintah memfasilitasi sebuah program untuk memastikan bahwa sarana peningkatan taraf ekonomi masyarakat di sekitar hutan dapat dilakukan dengan model penciptaan keselarasan antara peningkatan taraf ekonomi masyarakat dengan keberlanjutan lingkungan yang selalu dijaga kelestariannya. Program ini adalah program perhutanan sosial yang salah satunya dijalankan di Provinsi Kepulauan Bangka Belitung. Adapun data jumlah luas dan izin perhutanan sosial di provinsi tersebut disajikan pada tabel. 1 berikut :

Tabel 1 Data Jumlah Luas dan Izin Perhutanan Sosial di Provinsi Kepulauan Bangka Belitung

\begin{tabular}{|c|c|c|c|c|c|c|}
\hline \multirow[t]{2}{*}{ No } & \multirow[t]{2}{*}{ Kabupaten } & \multicolumn{3}{|c|}{ Izin Perhutanan Sosial } & \multicolumn{2}{|c|}{$\begin{array}{l}\text { Luas Areal Perhutanan Sosial } \\
(\mathrm{Ha})\end{array}$} \\
\hline & & HD & HTR & HKM & HTR & HKM \\
\hline 1 & Belitung/ Belantu Mendanau & 3 & 22 & 19 & 3.436 & 13.640 \\
\hline 2 & Belitung Timur/ Gunung Duren & 1 & 197 & 11 & 1.856 & 6.004 \\
\hline 3 & Bangka Tengah/ Sungai Sembulan & 2 & 9 & 8 & 342 & 4.299 \\
\hline 4 & Bangka Selatan/Muntai Palas & 0 & 1 & 3 & 2.405 & 134 \\
\hline 5 & Bangka Barat/ Jebu Bembang Antan & 0 & 2 & 3 & 399 & 744 \\
\hline 6 & Bangka/Bubus Panca & 0 & 2 & 12 & 120 & 909 \\
\hline 7 & Bangka/ Sigambir Kotawaringin & 0 & 1 & 8 & 29 & 631 \\
\hline \multirow[t]{2}{*}{8} & Bangka Barat/ Rambat Menduyung & 0 & 38 & 0 & 369 & 0 \\
\hline & Jumlah Total & 6 & 272 & 64 & $8.955,97$ & $26.361,00$ \\
\hline
\end{tabular}

Sumber: Diolah Peneliti, 2020 
Berdasarkan tabel. 1 diatas, dijelaskan terkait jumlah izin program perhutanan sosial dan luas areal perhutanan sosial. Kondisi eksisting yang ada saat ini, ada 64 izin hutan kemasyarakatan yang dikeluarkan oleh Pemerintah Provinsi Kepulauan Bangka Belitung dengan luas areal sekitar 26.361 hektar. Program perhutanan sosial yang dijalankan ini memiliki dampak dalam peningkatan taraf ekonomi masyarakat melalui pendekatan pemberdayaan dengan tetap mengedepankan pada aspek kelestarian. Program perhutanan sosial akan memberi kesempatan secara terbuka bagi masyarakat yang tinggal di wilayah hutan untuk mengajukan hak pengelolaan area hutan kepada pemerintah. Pasca mendapat persetujuan, tentu masyarakat dapat mengolah dan memanfaatkan hutan tersebut dengan caracara yang berdampak baik terhadap lingkungan. Adapun skema penyiapan akses perhutanan sosial dapat dilihat pada gambar 1 berikut :

Gambar 1 Skema Penyiapan Akses Perhutanan Sosial

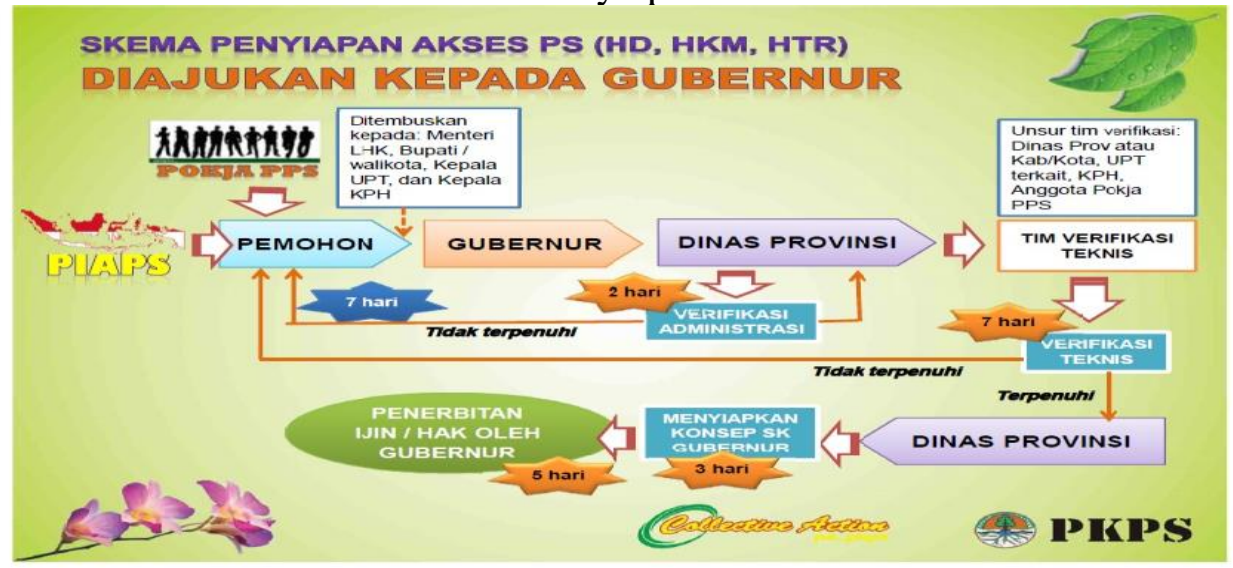

Sumber: Diolah peneliti, 2020

Berdasarkan pada gambar. 1 tersebut, untuk mendapatkan akses pengelolaan perhutanan sosial, maka pemohon perhutanan sosial mengajukan surat permohonan pengelolaan perhutanan sosial kepada gubernur yang ditembuskan kepada Menteri yang menaungi bidang kehutanan. Berdasarkan gambar.1 tersebut, juga terdapat waktu pelayanan untuk mengurus surat izin pengelolaan perhutanan sosial. Di Bangka Belitung, salah satu kelompok masyarakat yang mengelola perhutanan sosial, dalam hal ini Hutan Kemasyarakatan (HKm) adalah kelompok masyarakat Hkm Gempa 01 Kurau Barat, Bangka Belitung (Dinas Kehutanan Provinsi Kepulauan Bangka Belitung, 2016). Kelompok ini merupakan generasi muda pencinta alam yang fokus pada ekowisata mangrove dan konservasi mangrove. Aktivitas kelompok ini sudah dimulai dari tahun 2005 dan mendapat legalitas pengelolaan hutan kemasyarakatan pada tahun 2016. Adapun legalitas kelompok HKm yang ada di Kabupaten Bangka Tengah dapat dilihat pada tabel 2 berikut :

Tabel 2 Legalitas Kelompok HKm di Kabupaten Bangka Tengah

\begin{tabular}{ccccc}
\hline No & Nama Kelompok & Dasar Hukum & $\begin{array}{c}\text { Pesonil } \\
\text { Kelompok } \\
\text { Hutan }\end{array}$ & $\begin{array}{c}\text { Luas Areal } \\
\text { Kerja }\end{array}$ \\
& Kemasyarakatan & & & \\
\hline & Kelompok Tani & SK Gubernur Babel Nomor: & 18 orang & 213 hektar \\
1 & Generasi Muda & $188.44 / 209 /$ Dishut/2016 & & \\
& Pencinta Alam 01 & & & \\
\hline
\end{tabular}




\begin{tabular}{ccccc}
\hline 2 & $\begin{array}{c}\text { Kelompok Tani } \\
\text { Gempita Kurau Timur }\end{array}$ & $\begin{array}{c}\text { SK Gubernur Babel Nomor: } \\
188.44 / 285 / \text { Dishut/2016 }\end{array}$ & 36 orang & 148 hektar \\
\hline \multirow{2}{*}{3} & Kelompok Tani & SK Gubernur Babel Nomor: & \multirow{2}{*}{ 26 orang } & 300 hektar \\
\hline
\end{tabular}

Sumber: Diolah Peneliti, 2020

Berdasarkan tabel. 2 diatas, kelompok tani HKm Gempa 01 Kurau Barat merupakan salah satu kelompok tani yang diberikan izin dalam pengelolaan dan pemanfaatan perhutanan sosial di Bangka Belitung. Dengan demikian, kelompok tani tersebut akan difasilitasi untuk memperoleh dukungan-dukungan yang dapat diberi pemerintah daerah dalam hal mengelola hutan kemasyarakatan pada area kerja yang mereka ajukan. Program HKm yang bertujuan untuk meningkatkan kesejahteraan masyarakat dan kelestarian hutan memiliki makna bahwa efektivitas program $\mathrm{HKm}$ harus memberikan manfaat ekonomi bagi masyarakat dan manfaat ekologi bagi hutan (Andryansah, Nurrochmat, \& Kosmaryandi, 2019). Dukungan yang diberikan bagi kelompok HKm dapat diberikan pasca terbitnya izin pengelolaan perhutanan sosial oleh pemerintah agar kegiatan $\mathrm{HKm}$ berjalan secara optimal dan berkelanjutan (Moeliono et al., 2015).

Dengan program perhutanan sosial, masyarakat yang tergabung dalam kelompok tani yang diberi izin dapat memiliki akses kelola hutan dan lahan yang setara dan luasannya sebagaimana yang diberi izin. Bentuk pemanfaatan hasil hutan dilakukan sesuai prinsip kelestarian yang ramah lingkungan. Dengan demikian, tujuan konservasi lingkungan dapat sejalan dengan upaya peningkatan taraf ekonomi dan kesejahteraan masyarakat. Manfaat lainnya yang didapat adalah pelibatan masyarakat di sekitar hutan sebagai pihak utama dan terdekat yang menjaga kelestarian hutan. Provinsi Kepulauan Bangka Belitung memiliki kawasan seluas kurang lebih 40 persen dari luas wilayah Provinsi dan potensi yang ada di dalamnya harus dikelola secara baik. Perhutanan Sosial adalah salah satu program yang menjadi perhatian Pemerintah Provinsi Kepulauan Bangka Belitung dalam rangka pengelolaan sumber daya hutan secara lestari.

Potensi sumber daya alam di kawasan hutan yang sangat besar, baik jasa lingkungan wisata alam, pemanfaatan agroforestry, hasil hutan bukan kayu, maupun lainnya perlu dioptimalkan. Oleh karena itu, sebagai salah satu upaya optimalisasi tersebut, pemerintah berusaha untuk mendorong terwujudnya pengelolaan sumber daya hutan berbasis masyarakat melalui skema perhutanan sosial. Dinas Kehutanan Provinsi Kepulauan Bangka Belitung berkomitmen untuk terus mengembangkan perhutanan sosial, harapannya adalah agar masyarakat pemegang izin perhutanan sosial berdaya dalam memanfaatkan izinnya sesuai dengan koridor peraturan perundang-undangan yang berlaku untuk meningkatkan kesejahteraan sekaligus mempertahankan serta meningkatkan kelestarian hutan yang dikelola. Untuk itu diperlukan kesepahaman oleh semua pihak yang berkepentingan, untuk bersamasama mengembangkan perhutanan sosial di Kepulauan Bangka Belitung. Berdasarkan hal tersebut di atas, maka peneliti menganggap perlu untuk dilakukan penelitian dengan judul "Collaborative Governance Dalam Pemanfaatan Perhutanan Sosial Pada HKM Gempa 01 Kurau Barat Bangka Belitung”.

\section{METODE PENELITIAN}


Metode penelitian merupakan cara ilmiah yang digunakan untuk mendapatkan data dengan tujuan tertentu (Sugiyono, 2012). Untuk memudahkan proses penelitian, maka metode penelitian yang peneliti pergunakan dalam penelitian ini adalah desain penelitian dengan pendekatan kualitatif. Fokus penelitian ditetapkan dalam upaya untuk mempertajam penelitian. Penelitian ini adalah penelitian yang fokus membahas bagaimana pelaksanaan collaborative governance dalam pemanfaatan perhutanan sosial pada HKm Gempa 01 Kurau Barat Bangka Belitung. Terdapat empat indikator yang menjadi acuan dalam menganalisis bagaimana pelaksanaan collaborative governance dalam pemanfaatan perhutanan sosial di Provinsi Kepulauan Bangka Belitung, yaitu: dialog tatap muka, membangun kepercayaan, komitmen terhadap proses, saling memahami dan hasil sementara.

\section{HASIL DAN PEMBAHASAN}

Secara teoritis, ide tentang HKm bisa ditelusuri dari teori Community Based Forest Management (CBFM) sebagai pendekatan baru dalam tata kelola hutan yang berbeda dengan pendekatan konvensional. CBFM dipahami sebagai pemberian kewenangan kepada masyarakat lokal dengan tujuan supaya menjadi lestari dan masyarakat di sekitar hutan menjadi sejahtera. Sementara dalam konteks kebijakan kehutanan di Indonesia, CBFM ini diterjemahkan melalui kebijakan HKm. Hutan Kemasyarakatan didefinisikan sebagai kawasan hutan yang dimiliki oleh negara yang didalamnya berupa area hutan lindung atau hutan produksi yang dapat dioptimalkan dan ditujukan untuk kepentingan masyarakat yang tingga di sekitar kawasan hutan agar berdaya dan bernilai guna. Pemerintahan kolaboratif tentunya dijalankan dengan harapan dapat menemukan konsensus yang sejalan dengan permasalahan yang ada.

Kerjasama dengan pemangku kepentingan tentunya didukung dari internal organisasi, penguatan kelembagaan dirasa sangat penting dalam pemerintahan kolaboratif ini sebagai salah satu modal dalam melaksanakan kerjasama (Tando, Sudarmo, \& Haryanti, 2019). Proses pemberdayaan bertujuan dalam rangka peningkatan kemampuan dan kemandirian masyarakat untuk mendapatkan manfaat yang bersumber dari kawasan hutan tersebut. Harapan lainnya, dengan adanya peningkatan kapasitas, mayarakat akan menjadi peduli dan peka untuk melakukan proteksi terhadap fungsi ekologis hutan (Purnomo, Ramdani, Setyadiharja, \& Muzwardi, 2018).

Program perhutanan sosial merupakan salah satu bentuk pemberdayaan yang ditawarkan pemerintah pusat melalui Kementerian Lingkungan Hidup dan Kehutanan dan dianggap sebagai terobosan dalam meminimalisasi terjadinya konflik pengelolaan hutan yang sempat terjadi selama ini. Terdapat perbedaan kepentingan antara aktor yang terlibat dalam program perhutanan sosial dan persoalan teknis di lapangan sehingga persoalan berupa hakhak masyarakat menjadi pemicu konflik baru dalam tata kelola kawasan hutan (Sumanto, 2009).

Secara umum collaborative governance adalah sebuah regulasi yang mengatur beberapa lembaga publik secara langsung terlibat dengan pemangku kepentingan non publik dalam proses pengambilan keputusan secara kolektif bersifat formal, berorientasi konsensus, dan musyawarah yang bertujuan untuk membuat atau mengimplementasikan kebijakan publik atau mengelola program atau aset publik (Ansell \& Gash, 2008). Collaborative Governance merupakan sebuah proses yang di dalamnya melibatkan berbagai stakeholder yang terkait 
untuk mengusung kepentingan masing-masing instansi dalam mencapai tujuan bersama (Cordery, 2004;Hartman et al.,2002; Febrian, 2016).

Definisi hampir serupa disampaikan oleh Balogh (2011) bahwa Collaborative Governance merupakan sebuah prosess dan struktur dalam manejemen dan perumusan keputusan kebijakan publik yang melibatkan aktor-aktor yang secara konstruktif berasal dari berbagai level, baik dalam tataran pemerintahan dan atau instansi publik, institusi swasta dan masyarakat sipil dalam rangka mencapai tujuan pubik yang tidak dapat dicapai apabila dilaksanakan oleh satu pihak saja. Model Collaborative Governance menurut Ansell and Gash yaitu fakta yang melatarbelakangi suatu kolaborasi, dimana para pemangku kepentingan memiliki tujuan dan visi bersama yang ingin dicapai dalam konteks kerjasama yang dimulai dari sejarah, saling menghormati, aktor yang saling percaya, kemampuan dan pengetahuan yang berbeda antar aktor yang terlibat dalam kerjasama (Cahyono, 2020). Collaborative governance dalam konteks program perhutanan sosial pada HKm Gempa 01 Kurau Barat Bangka Belitung dianalisis menggunakan pendekatan collaborative governance menurut (Ansell \& Gash, 2008) dengan tahapannya dimulai dari dialog tatap muka, membangun kepercayaan, komitmen terhadap proses, saling memahami dan hasil sementara. Secara lebih rinci, tahapan-tahapan tersebut akan diuraikan sebagai berikut:

\section{Dialog Tatap Muka}

Dalam tatap muka antar stakeholder baik dari pihak pemerintah, masyarakat maupun swasta/dunia usaha dapat dibahas tentang apa, siapa, kapan, dimana, mengapa dan bagaimana. Pertanyaan-pertanyaan ini sangatlah penting dalam merencanakan dan melaksanakan (Hadilinatih, 2019). Menurut (Ansell \& Gash, 2008), collaborative governance proses awalnya dilakukan dengan membangun percakapan atau komunikasi secara tatap muka antar pemangku kepentingan yang terlibat dalam program yang dilakukan, dalam hal ini program perhutanan sosial pada HKm Gempa 01 Kurau Barat, Bangka Belitung. Dalam kolaborasi dibutuhkan adanya komunikasi multiarah. Komunikasi multiarah yakni adanya umpan balik yang berlangsung dengan melibatkan lebih dari dua pihak yang berlangsung secara berkelanjutan dengan intensitas yang tinggi.

Membangun konsensus yang diawali dengan komunikasi tatap muka merupakan proses penting dalam kolaborasi program tersebut. Dalam konteks program pengembangan dan pemberdayaan masyarakat pada kegiatan usaha pemanfaatan hutan di Kurau Barat Bangka Belitung proses dialog tatap muka ini pertama kali dilakukan pertemuan antar pemangku kepentingan yang terlibat, mulai dari kelompok masyarakat yang ingin mengembangkan potensi desa, masyarakat Desa Kurau Barat sebagai daerah sasaran, Pemerintah Desa, Pemerintah Kabupaten Bangka Tengah, Pemprov Babel, serta Kementerian LHK RI sebagai aktor pemerintah di level pusat. Setelah berdialog tatap muka, maka program prioritas yang dilaksanakan di Kurau Barat adalah program rehabilitasi kawasan hutan kritis agar menjadi asri dan mempunyai daya tarik wisata.

\section{Membangun Kepercayaan}

Setelah proses dialog tatap muka dilaksanakan, langkah berikutnya adalah membangun komunikasi yang baik antar pemangku kepentingan yang terlibat dalam kolaborator program perhutanan sosial pada Hkm Gempa 01 Kurau Barat Bangka Belitung. Dalam tahap ini, collabarative governance dalam program perhutanan sosial pada $\mathrm{HKm}$ 
Gempa 01 Kurau Barat Bangka Belitung membangun kepercayaan melalui interaksi yang dilakukan secara intens pada saat dialog tatap muka, khususnya pada saat diskusi dan koordinasi dalam menentukan kegiatan prioritas yang dilaksanakan di Kurau Barat, Provinsi Kepulauan Bangka Belitung.

Membangun kepercayaan semakin menguat setelah kegiatan prioritas yang diputuskan secara bersama antar aktor pemangku kepentingan dapat direalisasikan dan memberi dampak yang baik bagi masyarakat Kurau Barat, yakni meningkatnya pengembangan sektor wisata dan tercapainya arah kebijakan dalam meningkatkan PAD (Pendapatan Asli Desa) di Desa Kurau Barat. Pada tahap ini, yang dilakukan adalah membangun dan melaksanakan diskusi intensif dengan pemangku kepentingan yang berhubungan dengan hutan kemasyarakatan terkait formulasi dan strategi pengelolaan ekosistem mangrove berbasis kemasyarakatan di Desa Kurau Barat Bangka Belitung.

Tabel 3 Role Sharing Pelaksana Program Perhutanan Sosial Pada HKm Gempa 01 Kurau Barat Bangka Belitung

\begin{tabular}{|c|c|c|}
\hline No & Instansi & Peran \\
\hline 1 & $\begin{array}{l}\text { Pemerintah } \\
\text { Kepulauan } \\
\text { Belitung }\end{array}$ & $\begin{array}{l}\text { Pemberian Izin Usaha Pemanfaatan HKm kepada Kelompok Tani } \\
\text { Gempa } 01 \text { Kurau Barat }\end{array}$ \\
\hline 2 & $\begin{array}{l}\text { BPDASHL (Balai } \\
\text { Pengelolaan Daerah } \\
\text { Aliran Sungai dan } \\
\text { Hutan Lindung) } \\
\text { Baturusa Cerucuk }\end{array}$ & $\begin{array}{l}\text { Penyediaan } 100.000 \text { Batang tanaman Mangrove untuk menjaga } \\
\text { ekosistem Mangrove di Kurau Barat }\end{array}$ \\
\hline 3 & $\begin{array}{ll}\text { Dinas } & \text { Kehutanan } \\
\text { Provinsi } & \text { Kepulauan } \\
\text { Bangka Belitung }\end{array}$ & $\begin{array}{l}\text { Penataan kawasan mangrove secara terpadu untuk peningkatan ekonomi } \\
\text { masyarakat, sosialisasi dan penyuluhan ekosistem mangrove, } \\
\text { pendampingan kelompok dan lembaga desa dalam pengelolaan HKm, } \\
\text { pengembangan kemitraan dalam pengelolaan ekosistem mangrove } \\
\text { berbasis masyarakat. }\end{array}$ \\
\hline 4 & $\begin{array}{l}\text { Pemkab } \\
\text { Tengah }\end{array}$ & $\begin{array}{l}\text { Membangun infrastruktur pada HKm Mangrove Munjang Kurau Barat, } \\
\text { Pelatihan teknis dan studi banding pengelolaan HKm }\end{array}$ \\
\hline 5 & $\begin{array}{l}\text { Kelompok } \\
\text { Gempa } 01 \quad \text { Kurau } \\
\text { Barat }\end{array}$ & $\begin{array}{l}\text { Menyusun program pada areal kerja HKm, pengembangan ekowisata } \\
\text { mangrove berbasis masyarakat, mengembangkan kemitraan dalam } \\
\text { pengelolaan ekosistem mangrove berbasis masyarakat }\end{array}$ \\
\hline 6 & $\begin{array}{l}\text { Pemerintah } \\
\text { Kurau Barat }\end{array}$ & $\begin{array}{l}\text { Memberikan penguatan kebijakan kepada kelompok tani Gempa } 01 \\
\text { dalam pengelolaan } \mathrm{HKm} \text {, Melakukan pengawasan dan monitoring } \\
\text { terhadap program dan manajerial kelompok tani Gempa 01, memberikan } \\
\text { kepastian dan dukungan anggaran desa untuk pengelolaan } \mathrm{HKm}\end{array}$ \\
\hline
\end{tabular}

Sumber: Diolah peneliti, 2020

Berdasarkan tabel 3. diatas, proses membangun kepercayaan antar stakeholders disesuaikan dengan pembagian peran yang ada, mulai dari penyiapan program, proses 
pendampingan dan penguatan kebijakan dalam perhutanan sosial pada HKm Gempa 01 Kurau Barat Bangka Belitung.

\section{Komitmen Terhadap Proses}

Dari beberapa literatur yang dijadikan referensi, komitmen terhadap proses antar pemangku kepentingan adalah faktor yang menentukan berhasil atau gagalnya collaborative governance (Faidati \& Muthmainah, 2019). Proses kolaborasi dalam program perhutanan sosial pada HKm Gempa 01 Kurau Barat Bangka Belitung dalam aspek komitmen terhadap proses yang dilakukan Pemprov Babel melalui Dinas Kehutanan, Dinas Pariwisata, Dinas Perikanan, Dinas Pekerjaan Umum dan Perumahan Rakyat (PUPR) dan Masyarakat Kurau Barat yang memiliki tujuan yang sama dalam program perhutanan sosial khususnya dalam kegiatan pengembangan ekowisata dan rehabilitasi lahan yang muaranya untuk meningkatkan PAD (Pendapatan Asli Desa).

Tugas yang dilakukan pemerintah dalam hal penyediaan anggaran dilakukan untuk pembangunan sarana dan prasarana, promosi wisata dan akses jaringan kerjasama antar pemangku kepentingan yang berpengaruh nyata terhadap efektivitas program HKm Gempa 01 Kurau Barat Bangka Belitung. Ada beberapa tugas dan peran yang dapat dilakukan pemerintah, baik di level pusat maupun daerah dalam program perhutanan sosial. Pemerintah pusat memiliki tugas dalam penyelenggaraan pembinaan, sementara pemerintah daerah mempunyai tugas dalam fasilitasi pembinaan HKm Gempa 01 Kurau Barat. Peningkatan peran dalam hal penyediaan anggaran dilakukan oleh pemerintah pusat. Sedangkan pemerintah daerah melakukan tugas pendampingan, pelatihan dan promosi usaha wisata bagi kelompok HKm Gempa 01 Kurau Barat dan membangun komunikasi yang intensif dengan sektor pariwisata yang ada di Bangka Tengah dan pemerintah desa Kurau Barat. Peran pembinaan ini harus dikoordinasikan agar berjalan secara sinergis antar jenjang pemerintahan yang ada baik di tingkatan pusat maupun tingkatan daerah (Andryansah et al., 2019).

Dalam kerjasama antar pemangku kepentingan yang terlibat dalam program perhutanan sosial sudah berjalan sangat baik. Hal ini bisa dilihat bagaimana cara Kelompok Tani Gempa 01 Kurau Barat Bangka Belitung bisa mengantisipasi tumpang tindih kebijakan dari Pemerintah Pusat dan Pemerintah Provinsi sehingga dikeluarkannya Peraturan Desa untuk mendukung program tersebut. Peraturan Desa tersebut dibuat agar program perhutanan sosial pada HKm Gempa 01 Kurau Barat dapat berjalan secara efektif dengan memperhatikan kondisi yang ada di Kurau Barat Bangka Belitung.

\section{Saling Memahami}

Dalam collaborative governance, para aktor yang terlibat harus menyamakan persepsi akan tujuan yang hendak dicapai secara bersama. Dalam tahap ini, kesepakatan mengenai penguasaan pengetahuan yang berkaitan dengan program tersebut berperan untuk mengurai persoalan. Tahap saling memahami dalam program Perhutanan Sosial pada HKm Gempa 01 Kurau Barat Bangka Belitung berjalan cukup baik. Hal ini ditandai dengan program yang dilakukan antar aktor yang terlibat terintegrasi. Saling memahami ini merupakan misi bersama, tujuan bersama untuk memecahkan permasalahan yang ada di Kurau Barat Bangka Belitung dalam hal ini bagaimana meningkatkan dan mendorong kemandirian ekonomi masyarakat desa melalui kegiatan pengembangan ekowisata mangrove dan konservasi mangrove. Saling memahami dalam hal ini dimaksudkan untuk dapat mengerti akan 
permasalahan, kebutuhan, tugas dan wewenang masing-masing pihak, sehingga kebijakan dan keputusa-keputusan yang diambil diupayakan dapat semaksimal mungkin mengakomodir kebutuhan dan keinginan pihak-pihak terkait (Hadilinatih, 2019).

Adapun strategi implementasi dalam program perhutanan sosial pada HKm Gempa 01 Kurau Barat Bangka Belitung pada tahap saling memahami ini adalah penyediaan data dasar ekosistem mangrove munjang Kurau Barat dan kemudian dianalisa menjadi informasi yang dapat dimanfaatkan untuk sumber informasi sosial ekonomi kemasyarakatan. Setelah itu, menyediakan infrastruktur untuk memajukan pariwisata mangrove munjang kurau berupa mangrove information center, tempat pembibitan mangrove dan kapal motor yang digunakan untuk mengelilingi kawasan hutan mangrove yang dikelola oleh kelompok tani Gempa 01 Kurau Barat Bangka Belitung.

\section{Hasil Sementara}

Beberapa studi kasus memperlihatkan bahwa kemitraan sangat fisibel dilakukan ketika tujuan dan keuntungan dari kolaborasi relatif konkrit. Keberhasilan collaborative governance akan memberikan umpan balik ke dalam proses kolaboratif, mendorong terjadinya perubahan yang baik untuk membangun sebuah tumpuan dan keterikatan.

Target utama satuan kegiatan program perhutanaan sosial terhadap HKm Gempa 01 adalah pengembangan ekowisata (jasa lingkungan), konservasi mangrove, pendidikan lingkungan, dan persemaian. Dengan adanya pengembangan ekowisata mangrove memberikan dampak ekonomi kepada masyarakat sekitar dan anggota kelompok masyarakat melalui jasa parkir, bibit tanaman, area pemancingan dan lain-lain. Selain itu dengan terjaganya ekosistem mangrove yang terjaga memberikan dampak terhadap peningkatan hasil tangkap nelayan seperti nelayan kepiting bakau.

Hasil sementara dari kolaborasi antar aktor kepentingan dalam program perhutanan sosial pada HKM Gempa 01 Kurau Barat Bangka Belitung adalah adanya tambahan penghasilan bagi masyarakat di sekitar hutan melalui berbagai kegiatan yang dikelola oleh kelompok tani HKm Gempa 01 Kurau Barat. Selain itu, hasil sementara yang sudah terlihat adalah diraihnya penghargaan Juara 1 Tingkat Nasional Kategori Hutan kemasyarakatan pada tahun 2019. Disamping itu, Ketua HKm Gempa 01 juga dinobatkan sebagai salah satu nominasi penerima penghargaan Kalpataru untuk kategori perintis lingkungan. Keberhasilan pengelolaan perhutanan sosial pada HKm Gempa 01 Kurau Barat Bangka Belitung karena memberi nilai ekonomi bagi masyarakat dan terselamatkannya ekosistem mangrove di Provinsi Kepulauan Bangka Belitung sehingga dijadikan role model dalam pengelolaan rehabilitasi mangrove di Bangka Belitung. 


\section{PENUTUP}

Pemanfaatan dan pengelolaan program perhutanan sosial di Kepulauan Bangka Belitung menjadi isu baru yang dapat terus dikembangkan. Perhutanan sosial merupakan bagian dari pemerataan ekonomi yang tujuannya untuk mensejahterakan masyarakat di sekitar hutan, khususnya yang terlibat dalam pengelolaan hutan kemasyarakatan dengan memberi akses kelola kepada masyarakat. Aktivitas pemberdayaan kelompok perhutanan sosial yang dalam hal ini dikelola oleh kelompok HKm Gempa 01 Kurau Barat Bangka Belitung dengan memeranutamakan pendamping sebagai fasilitator, komunikator, motivator dan dinamisator untuk mendorong proses pembelajaran di lapangan dan perilaku yang mendukung tata kelola dan tata usaha hutan secara berkelanjutan dan berkeadilan.

Dengan adanya program perhutanan sosial yang dikelola oleh HKm Gempa 01 Kurau Barat Bangka belitung, dampak yang diharapkan adalah peningkatan kesejahteraan masyarakat pemegang izin program perhutanan sosial, terjaganya kondisi kelestarian kawasan hutan yang dikelola oleh pemegang izin perhutanan sosial dan tercapainya pemerataan akses pengelolaan hutan oleh masyarakat melalui skema perhutanan sosial.

Dampak positif dari berbagai kegiatan pelestarian lingkungan oleh kelompok tani HKm Gempa 01 Kurau Barat Bangka Belitung bagi lingkungan sekitar diantaranya adalah mencegah abrasi, menahan peresapan air laut ke daratan, berkurangnya kandungan karbondioksida dan menghambat bahan-bahan pencemar di perairan pantai hutan mangrove Kurau Barat, sebagai tempat hidup biota laut, baik untuk berlindung, mencari makan, pemijahan maupun pengasuhan, menjadi sumber pendapatan bagi nelayan karena hutan mangrove yang dijaga kelestariannya membantu menjaga ketersediaan ikan, kepiting dan biota laut lainnya. Kawasan mangrove yang dikembangkan menjadi objek wisata juga dapat memberikan dampak ekonomi bagi masyarakat Kurau Barat dan meningkatkan kesadaran masyarakat tentang betapa pentingnya menjaga ekosistem mangrove sehingga tidak ada lagi yang melakukan penebangan liar di kawasan mangrove.

Dampak positif lainnya yang ditimbulkan dari kegiatan yang dilakukan kelompok tani HKm Gempa 01 Kurau Barat Bangka Belitung tersebut adalah perhatian dari pemerintah pusat dan juga pemerintah daerah. Hal ini dibuktikan dengan diberikannya bantuan dana dari Kementerian Lingkungan Hidup dan Kehutanan melalui Direktorat Jenderal Perhutanan Sosial dan kemitraan Lingkungan, serta kunjungan dari Gubernur Provinsi Kepulauan Bangka Belitung dalam acara penanaman yang dilaksanakan di lokasi ekowisata mangrove.

Adapun rekomendasi untuk program perhutanan sosial di Kepulauan Bangka Belitung adalah dukungan kebijakan dalam pengembangan perhutanan sosial terutama dalam upaya peningkatan efektivitas kelola usulan oleh para pemegang izin, dukungan kapasitas SDM dalam membantu percepatan pengembangan perhutanan sosial, perlunya sinergi antar struktur baik di tingkat organisasi perangkat daerah, para pelaku usaha maupun lembaga non pemerintah lainnya. Disamping itu, perlu pemanfaatan secara berkelanjutan dalam pengelolaan hutan kemasyarakatan hutan mangrove Kurau Barat dalam mendukung penerapan skema perhutanan sosial di Kepulauan Bangka Belitung. 


\section{DAFTAR PUSTAKA}

Andryansah, O., Nurrochmat, R. D., \& Kosmaryandi, N. (2019). Effectiveness Model of the Nature Tourism Based Community Forest Program Implementation in Bangka Tengah District. Media Konservasi, 24(2), 124-133.

Ansell, C., \& Gash, A. (2008). Collaborative governance in theory and practice. Journal of Public Administration Research and Theory, 18(4), 543-571.

Balogh, Stephen, dkk. 2011. An Integrative Framework for Collaborative Governance, Journal of Public Administration Research and Theory.

Cahyono, A. S. (2020). Implementasi Model Collaborative Governance Dalam Penyelesaian Pandemi Covid-19. Jurnal ilmu sosial dan ilmu politik, 13(1), 83-88.

Dinas Kehutanan Provinsi Kepulauan Bangka Belitung. Keputusan Gubernur Provinsi Kepulauan Bangka Belitung tentang Pemberian Izin Usaha Pemanfaatan Hutan Kemasyarakatan (IUPHKm) Kepada Kelompok Tani Gempa 01 di Dalam Kawasan Hutan Lindung Pelawan Desa Kurau Barat Kecamatan Koba Kabupaten Bangka Tengah. , Pub. L. No. 188.44/209 (2016).

Dinas Kehutanan Provinsi Kepulauan Bangka Belitung. Keputusan Gubernur Provinsi Kepulauan Bangka Belitung tentang Pembentukan dan Struktur Organisasi Kelompok Kerja Percepatan Perhutanan Sosial Kepulauan Bangka Belitung Tahun 2017-2022. , Pub. L. No. 188.44/1350 (2017).

Faidati, N., \& Muthmainah, N. F. (2019). Collaborative Governance Dalam Pengembangan UMKM di Era Revolusi Industri. Konferensi Nasional Ilmu Administrasi, 1-6. Bandung: STIA LAN Bandung.

Febrian, R. A. (2016). Collaborative Governance Dalam Pembangunan Kawasan Perdesaan (Tinjauan Konsep Dan Regulasi). Wedana: Jurnal Kajian Pemerintahan, Politik Dan Birokrasi, 2(2), 200-208.

Hadilinatih, B. (2019). Collaborative Governance Dalam Pemberantasan Korupsi. Jurnal Enersia Publika: Energi, Sosial, dan Administrasi Publik, 2(1).

Kementerian Lingkungan Hidup dan Kehutanan. Peraturan Menteri Lingkungan Hidup dan Kehutanan tentang Perhutanan Sosial, Pub. L. No. P.83/MenLHK/Setjen/Kum.1/10/2016 (2016).

Kementerian Lingkungan Hidup dan Kehutanan. Keputusan Direktur Jenderal Perhutanan Sosial dan Kemitraan Lingkungan tentang Pembentukan Kelompok Kerja Percepatan Perhutanan Sosial. , Pub. L. No. SK.23/PSKL/SET/KUM.1/9/2017 (2017).

Kuncoro, M. (2018). Dampak Perhutanan Sosial: Perspektif Ekonomi, Sosial dan Lingkungan. Jakarta: KLHK.

Moeliono, M., Mulyana, A., Adnan, H., Yuliani, E. L., Manalu, P., \& Balang. (2015). Ijin saja tidak cukup: Belajar dari hutan kemasyarakatan (HKm) Bulukumba. Bogor.

Nilasari, A., Murtilaksono, K., \& Soetarto, E. (2017). Tipologi konflik kawasan hutan pada proses penataan batas di wilayah Pulau Bangka. Sodality: Jurnal Sosiologi Pedesaan, 5(3), 176-183.

Purnomo, E. P., Ramdani, R., Setyadiharja, R., \& Muzwardi, A. (2018). Collaborative Governance Dalam Tata Kelola Hutan Berbasis Masyarakat. Yogyakarta. 
Putra, R. A. S., Muluk, S., Prayitno, H., Taufik, A., Salam, R., Nugraha, R., ... Sani, K. (2019). Pembiayaan Perhutanan Sosial di Indonesia.

Sugiyono. (2012). Metode Penelitian Kuantitatif, Kualitatif, dan Kombinasi (mixed methods). Bandung: CV Alfabeta.

Sumanto, S. E. (2009). Kebijakan pengembangan perhutanan sosial dalam perspektif resolusi konflik. Jurnal Analisis Kebijakan Kehutanan, 6(1), 13-25.

Susilo, Y. S. (2019). Dampak Perhutanan Sosial Terhadap Pendapatan Masyarakat. ISEI Economic Review, 3(1), 16-27.

Tando, C. E., Sudarmo, S., \& Haryanti, R. H. (2019). Pemerintahan Kolaboratif Sebagai Solusi Kasus Deforestasi di Pulau Kalimantan: Kajian Literatur. Jurnal Borneo Administrator, 15(3), 257-274. 